УДК 821.163.6.09 Шаламун Томаж https://doi.org/10.18485/godisnjak.2018.13.6

Горан П. Коруновић* Универзитет у Београду

Филолошки факултет
Оригинални научни рад Примљен: 14. 09. 2018. Прихваћен: 15. 10. 2018.

\title{
„НИСАМ СУБЈЕКТ. ОРМАН БОГА САМ” - ЛИРСКО ЈА У РАНОЈ ПОЕЗИЈИ ТОМАЖА ШАЛАМУНА ${ }^{* *}$
}

У раду се тумаче поступци обликовања лирског субјекта у раној поезији једног од назначајнијих словеначких песника XX века, Томажа Шаламуна, и то од дебитантске збирке Покер (1966) до Баладе за Метку Крашовеи (1981). Неовангардни видови реализације исказне инстанце у назначеном периоду посматрају се у светлу отклона од модернистичких начина моделовања лирске субјективности. Анализирају се поетичке улоге исказних инстанци Шаламунових песама и прати се њихова трансформација, од „маскираног” церебралног језгра исказивања у Покеру, преко израженијих неонадреалистичких пракси у каснијим збиркама, продора несвесног у ток исказивања и десемантизације језика, до повишене аутореференцијалности лирског Ја и парадоксалне реафирмације ауторске фигуре.

Кључне речи: Томаж Шаламун, лирски субјект, неоавангарда, несвесно, иронија, субверзија.

Током друге половине 60-их година XX века у поезији јужнословенских књижевности доминирају видови лирског субјекта карактеристични за модернистичке поетике, реализовани у широком распону: као „маске”

*g.korunovic@gmail.com

** Рад је резултат рада на пројекту Улога српске периодике у формирању књижевних, културних и националних образаща који финансира Министарство просвете, науке и технолошког развоја Републике Србије. 
песника, затим у облицима исказних инстанци космогонијско-метафизичких визија, често и као персоне које посредују одређено поимање историје, цивилизације и националне традиције, или пак као егзистенцијалистички и/или интимистички-исповедно профилисане исказне позиције. Седма деценија прошлог века, међутим, специфична је и по томе што у књижевном пољу постају уочљивије неоавангардне тенденције које, осим умножавања формално-конструктивних иновација, најчешће подразумевају и преиспитивање модернистичке представе субјекта и лирског исказивања. Управо је Томаж Шаламун један од аутора чија је улога родоначелничка у оквирима неоавангардног таласа. Он је већ 1964. године био примећен у југословенској књижевној јавности захваљујући политички субверзивној песми „Дума 1964", ${ }^{1}$ у којој лирско Ја уводи неколико сродних, нијансираних облика критике идеологије: најпре деидеологизовано, у назнакама чак и морализаторско становиште („О идеолози, у пратњи својих курви идеологија”, Šalamun 2013a), затим и иронично-козерско оспоравање револуционарних полазишта друштвеног уређења („о револуционарне масе или где је тај санаторијум/ што би нашу импотенцију лечио”, Šalamun 2013a). То прати и критички однос према тада актуелном виду социјалистичког поретка који је, из перспективе лирског Ја, оснаживао апсолутистичку власт и класне разлике („О социјализму а ла Луј XIV или како заштитити јадне животињице", Šalamun 2013a). Будући да се оспорава врло специфична друштвена реализација социјалистичке идеологије, не може се потпуно потиснути и могућност да лирски субјект ипак благонаклоно гледа на идеје произашле из марксистичке мисли, врло дискретно еманирајући став да је другачије остварење социјалистичког друштва нужно и могуће.

Већ је у претходним стиховима „Думе 1964” уочљиво да се неоавангардна природа текста пре свега препознаје у лудистичко-демистификаторском духу исказне инстанце, не нужно и на формално-конструктивном плану, будући да, од самог почетка стваралачког пута, слободни стих и облици Шаламунових песничких остварења најчешће не одражавају радикалније експерименталне поступке. Отуд ће предмет наше интерпретације бити управо начини формирања исказне инстанце у Шаламуновом раном песништву, од дебитантске збирке Покер (1966) до Баладе за Метку Крашовеи (1981) - то је период када је словеначки песник увео већину поступака обликовања лирског Ја по којима је препознатљиво његово стваралаштво, иако је након назначене етапе стварао више од три

${ }^{1}$ О заплени броја часописа „Perspektiva”, у којем је требало да се појави Шаламунова песма „Дума 1964”, као и о осталим репресивним реакцијама власти на Шаламуново стваралаштво, више у: Jacek Kozak 2014: 68-69. 
деценије. Осим тога, издвојена фаза поклапа се са књижевноисторијски релевантним годинама сусрета неоавангардних тенденција и модернистичке поетичке струје, те се управо у начинима моделовања лирског субјекта у Шаламуновом раном песништву може пратити путања неоавангардног превладавања модернистичких облика лирске субјективности и својеврсно проширење типолошке скале реализације лирског Ја у јужнословенским књижевностима.

\section{Мимикрија церебралног лирског Ја у Покеру}

Када се 1966. године појавила Шаламунова дебитантска збирка Покер, неоавангардни талас је већ у успону у словеначкој књижевности. Исте године почиње деловање уметничке групе ОНО, чији је утицај на токове концептуалне уметности у бившој Југославији неоспоран (Despotov 2005: 9; Šuvaković 1999: 151), док годину дана раније Франци Загоричник публикује збирку Агамемнон, својеврсну објаву поезије семантичког конкретизма ${ }^{2}$ и визуелне поезије, тзв. „ултрамодернизма” (Poniž 2001: 189; в. Grafenauer 2011: 1562-1566). У таквом, изразитије експерименталном стваралачком контексту, Шаламунова прва песничка књига постаје препознатљива управо по лирској субјективности која неоавангардни поетички учинак остварује у специфичној коресподенцији са модернистичким модалитетима лирског Ја.

Наиме, у многим песмама Покера се, као у ретко којој каснијој Шаламуновој збирци, може приметити да план исказивања није специфичан по радикалној дисперзивности, односно да је семантичка центрипеталност сведена на меру која у први мах може навести на мисао да је у основи реч о исказној инстанци која је лишена располућености, расапа сопства, уплива несвесног, о лирској субјективности која се, дакле, може пронаћи и у многим модернистичким песничким текстовима јужнословенских књижевности, и то у варијацијама које, наравно, „производе” партику-

\footnotetext{
${ }^{2}$ Када је реч о семантичком конкретизму, вреди напоменути да је посреди једна од најфреквентнијих пракси у оквирима неоавангардног таласа. Превасходно имамо на уму да се „семантичка конкретна поезија или семантички тоталитаризам, тотална поезија (Адриано Спатола) [...] гради од речи и сложених јединица са задржаним значењима, али одступајућим у односу на конвенционална значења и неподређеним једној централној идеји" (Despotov 2005: 7). То, укратко, подразумева „смањено судјеловање смисла као конститутивног елемента текста”, те се језик узима за „референцијално поље” (Vuković 2010: 164), што може подразумевати и изразитије експериментисање са визуелним и звучним аспектом песничког текста (Šuvaković 1999: 152-153).
} 
ларне поетике. ${ }^{3} \mathrm{C}$ друге стране, готово да нема песничког текста у Шаламуновој дебитантској збирци који доследно одражава исказну инстанцу блиску модернистичким типовима лирског Ја, будући да ток исказивања ипак бива дестабилисан низом песничких средстава, између осталог и лудистичко-игривим језичким и смисаоним обртима, уз поступке који не морају нужно бити препознати као праксе неоавангардне провенијенције: иронично-хуморном некомплементарношћу тона и теме, те понављањима одређених стихова који пре изискују изразитију интерпретативну пажњу него што чине исказивање проходнијим.

Поменуте песничке стратегије могу се наслутити, нпр. у 4. песми циклуса „Гљивице”: „Без тебе слово П свијет иде доврага/ парадајз пасмина политика/ (...)/ Без тебе слово П остаје још/ кремица аквамарин умазати намазати/ а све се заснива на паклицама/ (...)/ а онда хоћеш да спаваш али само зијеваш/ и зијеваш наг јер нема пиџаме/ тако се развија неморал/ тако се развија неморал/ перад поштар памтивјек" (Šalamun 2014: 25). Лирски субјект је специфичан по двогубом приступу теми уведеној првим стихом: најпре, може се препознати хуморно-травестијски став, „скривен” иза привидно афективне реакције пред назначеним проблемом, чију релеванцију сенче донекле тривијализовани означитељи („парадајз”, „кремица”, „перад”); с друге стране, и поред хуморног отклона, тема важности само једног издвојеног слова метонимијски отвара питање арбитрарности при самој пракси језичког означавања, евоцирајући

\footnotetext{
${ }^{3}$ Вреди нагласити да модернистичко лирско Ја монолошког и у основи континуираног исказивања заправо своју целовитост дугује - и поред потенцијалних трагова дигресивности, дисперзивних или херметичних семантичких импулса и/или моделовања несталности, кризних стања и амбиваленција - имплицитном поетичком поверењу у могућност језичке артикулације „унутрашњег света” и универзалних питања о човековом месту у свету и друштву. Прецизније казано, у модернистичкој лирици може бити речи, поред осталог, о недостатности људских снага, искустава и знања, с тим што то за последицу нема и проблематизацију самог феномена језика на начин који бива актуелизован тек у неоавангардним и постмодерним текстовима. Када се у модернистичким песмама немоћ језика наслути као мотив или као импликација одређеног поступка, она пре свега сведочи о самој људској немоћи, о ограниченом радијусу наших способности, о равни постојања која прекорачује нашу егзистенцију и употребу језика. Тиме се, ипак, не преиспитују начини успостављања језика као система и функционисања самих означитељских пракси. Често се чак рефлектују и стремљења (нпр. управо у егзистенцијалистичким или интимистичким модернистичким поетикама) да се и за недосегнута или неизрецива искуства пронађу одговарајући означитељи и језички еквиваленти, односно „објективни корелативи”. Са друге стране, у неоавангардној и постмодерној поезији самим обликотворним поступцима и концепцијама лирског субјекта отварају се питања арбитрарности знака, односа означитеља и означеног, разлике, друштвене условљености означитељских пракси, односа несвесне сфере субјекта и језика. Назначени заокрет у приступу феномену језика кореспондира са епохалним променама крајем 60-их и током 70-их година, белодано рефлектованим у успону деконструкцијског мишљења.
} 
посредно још један мотив, заступљен посебно у филозофском мишљењу - мотив логоцентризма. То је видљиво када се на крају последњег стиха, на семантички осетљивом месту, уводи лексема „памтивијек”, појам који наводи на мисао о ауторитету митског и метафизичког погледа на свет. И „памтивијек”, из перспективе лирског Ја, зависи од постојања слова „П”, те се тиме релативизује поменути ауторитет, али и само логоцентрично пренебрегавање (демитологизоване и метафизичких конотација лишене) арбитрарне позиције у процесу језичког означавања.

Ако свему овоме додамо да поновљени стих („тако се развија неморал/ тако се развија неморал") представља провизорно заузимање морализаторског става, заправо критичко-иронијски третираног из перспективе лирског Ја, постаје јасно да је реч о исказној позицији чија рефлексија није тек козерско поигравање, већ подразумева самосвесни одабир хуморне дистанце ради дискретнијег остваривања нијансираног приступа сложеним питањима као што је сам феномен језика и процес уобличавања значења. Лирски субјект преузима персону лудистичког хабитуса, да би учинио готово невидљивим церебрално језгро исказивања, при чему је таква мимикрија заправо сигнал да се, на својим почецима, Шаламунова поетика формира посредством односа према модернистичком наслеђу који није само оспоравалачки. ${ }^{4}$

Са друге стране, није неочекивано то да већ у Покеру постоје многе песме у којима је уочљива неонадреалистичка слободна асоцијативност, с тим што ће и такви елементи израза, за разлику од њихове пролиферације у потоњим збиркама, у дебитантској књизи неретко бити у служби потребе да се већ постављана крајња питања о човековом месту у свету лише патоса, предоче у хуморном светлу и прожму новим перспективима, као што је случај са сугерисаним приступом самом језику у 4. песми циклуса „Гљивице”. Све то, заправо, подразумева да се у случајевима изразитије примене неонадреалистичке песничке праксе, и поред уплива слободне асоцијативности, ипак указују особени поступци одржања рационалног аспекта лирског субјекта и одређене контроле тематских оквира

${ }^{4}$ Однос према делу Т. С. Елиота белодано показује да Покер, самим тим и шире разумевана Шаламунова поетика, поседују, блумовски казано, очинску фигуру у аутору Пусте земље. Стихови „прије два дана умро је Елиот/ мој учитељ” (Šalamun 2014: 38) могу се препознати као неприкривено упућивање на узора (Т. С. Елиот умире 4. јануара, године када излази Покер - 1965), док издвајање цитата на почетку 6. песме циклуса „Гљивице” (из Елиотовог текста "The Hippopotamus": “The 'potamus can never reach/ The mango on the mangotree”) (раз)открива специфично „криво читање” великог претходника, односно Шаламуново акцентовање, сходно сопственим поетичким аспирацијама, авангардних трагова у изразу песника Четири квартета. 
исказивања. Назначени ефекат спроводи се специфичним реторичким средствима, као што је, на пример, понављање идентичног глагола на почецима већине строфа у „Бајци са оранџадом”: „Волим пишингер/ и бајке са оранжадом/ (...)// волим животиње/ конобаре на југу/ (...)// волим Дантеа/ терасу у Опатији”, Šalamun 2014: 37), или лајтмотивским нитима у песми „Осми пут једе некако чудну храну”, које се окончавају у дискретној и пригушено критичкој историјско-политичкој алузији (,„и ако је у рижи сигурно једеш банане/ (...)/ маслачак једе папир// овсене пахуљице му дајемо/ ребра малољетника/ (...) Са смрћу ћу се борити/ али не тако као у здравим народним бајкама/ када смрт затворе буре/ потом мирно поседају/ жваћу сланину/ и тужно кажу/ Добердоб словенских момака гроб”, Šalamun 2014: 46). У Покеру, дакле, постоји специфична понорница рационалног плана субјективности која „прошива” само исказивање и рефлектује скривену копчу Шаламунове лирике са модернистичким поетичким хоризонтом.

Домети субверзије: лирски субјект песме „Зашто сам фашиста”

Пре него што пређемо на анализу лирског субјекта потоњих Шаламунових збирки, у којима ће брана према несвесном извору исказивања постати знатно порознија него у Покеру, неопходно је задржати се на конфигурацији лирског Ја у песми „Зашто сам фашиста”. Штампана бурне 1968. године, издвојена песма налази се на граници Шаламунове најраније фазе и добрим делом преноси вид провокативности која је била специфична за поједина остварења с почетка његовог песничког пута. Осим тога, песма „Зашто сам фашиста” репрезентује крајње идеолошке и естетске домете Шаламунових текстова у којима је полазиште исказивања, услед специфичне политичке и поетичке самосвести, карактеристичније по својој иронично-церебралној заснованости, него по несвесном аспекту субјективности.

Само тумачење песме неизоставно би морало почети од њеног провокативног наслова, који је у културно-политички миље социјалистичке Југославије експлицитно увео зазоран и трауматичан политички означитељ повезан са фашистичком идеологијом. Најпре би се могло поставити питање $\partial а$ ли је лирски субјект издвојене песме заиста „фашиста”, односно како лирско Ја разумева уведени идеолошки означитељ. Познати Адорнов исказ да после Аушвица није могуће писати песме, овде добија неку врсту радикалне, провокативне инверзије. 
Стиче се утисак да лирски субјект поменуте песме већ од првих исказа афирмише насиље као врховни, неупоредиви принцип живљења, с несумњивим (нео)футуристичким тоновима: „Доста ми је социјалне мимикрије. Само је/ убијање људи истинска акција, напета,/ узбудљива, фантастична. Ослушкује се,/ види, мирише, осећа и опипава цврчеће месо./ Блажени рат. Само мајка којој/ чизмом газиш синчићеву лобању заиста/ заурла са истинским болом и не треба да се/ бојиш да блефира./ А највећа истина/ је највећи извор естетског ужитка" (Šalamun 2013b). ${ }^{5}$ Реч је о персони која са својим окружењем, евидентно, не дели исте вредности и страсти, те мора прибегавати сузбијању, притворности, „камелеонском” ставу. Ипак, „социјална мимикрија” се не мора односити само на лирско Ја - сам исказ „доста ми је социјалне мимикрије” не искључује могућност да и шира заједница дели уверења лирског субјекта, с тим што она бивају потискивана због друштвене неприхватљивости.

Осим тога, већ се може наслутити и иронијско наличје персониног става. Опис реакције виолентног субјекта на бол жртве, посредством терминологије својствене нешто традиционалнијој естетичкој мисли (,,естетски ужитак”), дискретно је потирање границе између уметности и живота, али и успостављање њихове нове хијерархизације. Наиме, уколико је патња жртве извор најупечатљивијег естетског ужитка, онда се сва уметност мора подредити чину насиља који постаје мерило нове, фашистоидне аксиологије. Са друге стране, релативизација границе између уметности и живота својствена је (Шаламуну блиској) концептуалној уметности и body art тенденцијима с краја 60-их и током седамдесетих година, у оквиру којих се ревитализује фигура аутора/уметника и његовог животног искуства, чак и телесне боли (в. Đorđević 2016: 159-172; Denegri 2013: 29-30). Испоставља се да словеначки песник уводи лирски субјект који поседује иронијско наличје и само декларативно подразумева персону која афирмише фашистичка начела. Посредством апотеозе насиља заправо је упућена провокација конзервативним естетичким ставовима који бране стабилну маркацију између уметности и живота.

Ипак, уколико останемо у равни декодирања извесног виолентног етоса ове песме, препознајемо лирски субјект радикалне дехуманизације Другог: „Највећа информација је убити и измучити/ човека кога највише волиш”. Лирско Ја затим додаје: „Нисам загрижени присталица убијања странаца,/ незнанаца/ вреди убити само због новца, не/ због уметности. Ако војник убије војника,/ то је нешто просечно. Али када/ симпатичан,

${ }^{5}$ Познати су топоси италијанског футуризма о „блаженом рату”, о рату као ,јединственој хигијени света" у служби фашистичке Италије (Де Торе 2001: 87). 
леп, елегантан младић/ у наступу откине вилицу својој мајци/ или палцем пробуши мали отвор у лобањи/ свог бате док лежерно/ разговара, а његов религиозни, смирени,/ отворени и мудри поглед нимало не губи/ од своје невиности... О светлости!" (Šalamun 2013b). Већ након наведених стихова постаје јасно да није тек реч о изношењу експлицитније и неприкривено виолентне варијације фашистичке идеологије, већ пре о наглашавању уживањ а у злочину. Није посреди излагање аргументације у прилог одређеног политичког програма, како би се то могло наслутити из наслова, већ је на делу својеврсна дивинизаиија насиља, настојање да се оно прикаже у виду који би могао побудити епифанично искуство.

Лирски субјект, дакле, уводи означитељ „фашиста” као својеврсни „прошивни бод” (Žižek 2002: 125-128), доминантни означитељ који придаје смисао кумулацији одређених ставова, страсти, уверења, адаптирајући при томе, сходно сопственој пасији, његов у историји осведочен смисао. У наставку се, ипак, афирмишу и поједина општа места фашистичких/нацистичких уверења и предрасуда („Фашизам интегрише чисту/ лепоту. Фашизам значи младост, свежину,/ моћ, акцију и виталност, јеврејске свиње/ су труле/ (...)/ И волео бих да видим онога који би збиља/ више волео да буде бенав, слабуњав и прогоњен", Šalamun 2013b). То прати анимозитет према брачној заједници, осећање не сасвим компатибилно фашистичком разумевању породице ${ }^{6}$ и увођењу класне разлике, дистинкције која иде на руку фашистичком поретку („Милијардер лепше изгледа од/ занатлије, а брачни пар који се воли/ подсећа ме на дебелог гадног/ послужитеља који једе шкембиће", Šalamun 2013b). Све наведено одражава персону радикализоване, иако недовољно доследно изведене идеолошке матрице, формиране пре свега у служби апсолутизације зла и насиља, негативног аксиолошког принципа и тоталитарних идеолошких премиса.

У наставку, ипак, лирска субјективност постаје сложенија, и све израженије провејава њено иронично-критичко наличје. Томе иде у прилог и увођење хомосексуалног мотива, када, услед ојачавања иронијског аспекта исказивања, персона декларативно фашистоидног етоса афирмацијом хомосексуалности посредно сведочи о могућем постојању потиснуте, табуизиране хомосексуалне жеље и унутар фашистичке заједнице („Такође, фино је кад се два гола војника/ љубе”, Šalamun 2013b). У завршници песме исказна инстанца се јасније профилише као персона аутора/песника, будући да, осим непосредног (само)именовања, постоји и реферирање на друштвену стварност, на обавештајне службе тадашње

${ }^{6}$ Одбрана брака и породице у фашизму је пре свега повезана са одбраном тзв. чистоте pace (в. Morgan 2006: 221-222). 
Југославије (,Је ли бог био демократа кад је једним потезом/ одвојио воду од неба?/ Онај ко ме буде успео/ да увери у то направиће од Томажа Шаламуна/ овцу и унуци мојих унука покораваће се/ његовим потомцима./ А до тада остајем оно/ што сам, и све док не покупим довољно/ оружја, новца и људи, све док не/ прикупим довољно штофа за униформе мојих/ дечака, све док у војску и удбу не/ инфилтрирам довољно младих генија,/ писаћу песме о лепоти природе и/ скромно и тихо се припремати за/ велики дан”, Šalamun 2013b).

Када се, на концу песме, помиње и служба државне безбедности, посреди је посебан вид провокације јавног мњења, поготово када се има у виду песников боравак у затвору након објављивања песме „Дума 1964". Идентификациона веза исказне инстанце и ауторске фигуре, поткрепљена непосредним именовањем лирског Ја, заправо је један од фактора конституисања субверзивне лирске субјективности, будући да ствара предуслов иронијских импликација - наизглед сам емпиријски аутор афирмише фашистичку идеологију. Шаламун отуд моделује лирско Ја које је субверзивно на више нивоа. Најпре, читање које би идеолошку потку песме препознало као фашистичку, пренебрегава иронијско подривање назначеног тоталитаристичког идеолошког дискурса, посебно кроз афирмисање хомосексуалности од стране исказне инстанце која, наизглед, брани фашистичка уверења. Осим тога, инсистирањем на хипертрофираном уживању у насиљу призива се Де Садова мисао која je, максимализацијом опсцених жеља и поимањем зла као генеративног језгра људских прохтева и поступака, заправо имплицитно критиковала просветитељско-рационалистички оптимизам и пренебрегавање сеновите стране људске природе. За предмет песничке критике одабране су не само тоталитаристичке заједнице, већ и друштва која начелно и декларативно за своје темеље имају управо просветитељско-рационалистичке идеје, те услед тога потискују и негирају могућност да фашизам постане, можда у неком новом, трансформисаном и прикривеном облику, њихов аксиолошки ослонац и принцип функционисања. Томе свему вреди додати да се самим називањем лирског Ја именом аутора субверзивно приступа и модернистичком концепту о естетској аутономији књижевности - као што је на почетку песме критички третирана традиционална граница између уметности и живота, у завршници се релативизује и раздвајање емпиријске стварности од песничког текста. 


\section{Лирско Ја које себе не поседује}

Шаламун никада није потпуно одустао од полемичко-провокативних интенција; ипак, део његовог опуса током 70-их година не задржава се само на таквом виду лирског израза. Може се заправо рећи да се од Ходочашћа за Марушку (1971) до Баладе за Метку Крашовец (1981) интензивно испољава један од основних парадокса Шаламуновог изражајног модуса - уз сталне трансформације лирског Ја, задржавају се и одређене препознатљиве константе у обликовању лирске субјективности.

Делимично и пре Ходочашћа за Марушку (1971), а од те збирке посебно, јасно је да је Шаламуново песништво у основи неонадреалистичко. Исказивање лирског Ја у поменутој збирци прати слободне асоцијативне флуксеве уз изразиту сегментацију стихова зарезима, чиме се постиже утисак да ниједан фрагмент вербалне „масе” није смисаоно привилегованији од осталих. „Ја сам тигар/ у срцу зова, у теби клија душа, did she?/ (...)/ о светло, размакни загрејаност/ поједи воће, ољушти сјај робе/ ливаде су раскомадане, газеле су брже/ морбидност, тамни прсти лепоте кафе/ рушевина̂, femme, тренутака гравитације" (Шаламун 1974: 53); „креч у пустињи, пет сантиментара подигнут зид/ љубљана, град, руже од огромног смеђег дрвета/ делфини, угаљ, трактор на земљи" (Шаламун 1974: 59). Ови и слични стихови пример су продуковања потенцијално недовршивог низа дисперзивних слика, смисаоно међусобно некомплементарних синтагми, лексема̂ удаљених семантичких поља, делинеаризованог склопа констатација без наговештаја обједињавајућег контекста. Све то спорадично прате уметнута питања (,ко одржава глад неба?/ куда ћемо са минђушама, младим поручницима?/ уморним морнарима?”, Шаламун 1974: 77), која не откривају довољно конкретно обрисе лирских ситуација или пак тежње исказне инстанце, те рационална страна лирског Ја и логика његовог исказивања остају затамњени.

Ток исказивања само привидно представља отргнуте делове неке претпостављене целине - неке компактне или довршене рефлексије, одређеног ситуационог оквира и околности са којима су покидане референцијалне везе, или пак неког иницијално јасног и недвосмисленог осећања. Отуд можемо говорити о лирском Ја чије исказивање не формира језичке еквиваленте емоција и афективних реакција, одређених идеја и рефлексија, као што је преовлађујући случај у модернистичким поетикама. У Шаламуновим песмама пре је реч о својеврсној десемантизацији песничког језика, кумулацији означитеља која враћа „излагање на станице речи. [...] Ове речи-објекти без међусобне повезаности, урушене свом 
жестином свог избијања, чије чисто механичко треперење чудно дотиче суседну реч, али се одмах затим гаси, ове песничке речи искључују људе" (Bart 1971: 61-62).

Шаламунова поезија са самог почетка 70-их година, дакле, „призива” бартовско разумевање писањ $а$ и надилази представу о кохерентном, исповедном лирском Ја као полазишту исказивања, јер је „искрена позиција већ увек - парадоксално, зар не? - изврнута, субвертирана. Тамо где досегне лажна дистанца 'осећања' и 'осећаја', једина ствар која уистину постоји биће само и у првом реду једино тотални, физички заветан ритуал писања" (Debeljak 1986: 171). Ипак, то не мора да значи потпуно нестајање субјективности - сугерисана означитељска пракса најподобнија је за оглашавање „отисака” несвесне сфере субјекта, која ишчезава самим обзнањивањем у било којем дискурсу и која је у основи увек присутна само као већ одсутна (в. Fink 2009: 48-49; 52; в. Lacan 1986: 23-34).

У песмама Ходочашћа за Марушку „говори”, дакле ја у име субјекта који себе већ не поседује, предаје се развлашћеном језику и продору несвесног у означитељском ,ланцу”, што Шаламуново рано песништво евидентно ситуира на трасу неонадреалистичке поетике. Може се рећи и да је у Ходочашћу за Марушку спроведено оспоравалачко и радикално дистанцирање од интимистичке и егзистенцијалистичке лирске субјективности, уз настојање да се сам ток исказивања укаже као својеврсна „материјализација” несвесних предвербалних „струјања”. Другим речима, од лирике Ходочашћа за Марушку нећемо много добити уколико се усредсредимо на семантички план, разуђен, акциденталан, зависан од контингентних веза између елиптичних исказа, без наговештаја интегришућег хоризонта; једнако је непродуктивно очекивање да ће се у интерференцији исказа/слика јасније указати „лице” лирског субјекта, подложно психологизацији или пак ситуирано у одређеном простору/времену. Реч је заправо о парадоксу по којем радикализација „искрености” лирског Ја, тј. ослобађање недиригованог принципа генерисања тока исказивања с ослонцем на несвесно, доводи до конфигурације лирског субјекта која је специфична управо по „укидању” исповедног, „искреног” језгра које стреми непосредованом изношењу „унутрашњих” садржаја или пак проналажењу „објективних корелатива”. Лирски субјект се, дакле, преображава у „место” реализације одређене песничке праксе, препознатљиве по „утискивању” несвесног у дискурс и његовом истовременом ишчезавању, по обезличавању субјекта у којем је заменица ,ја” само „маска”, замена никада досегнутог „лица без лица" несвесног. 
Сходно томе, у Шаламуновој раној поезији профилише се и непоуздан имплицитни аутор (в. O’Neill 1994: 70). ${ }^{7}$ Ако је одређени аспект имплицитног аутора у овом типу песништва поуздан и евидентан, онда је то без сумње задржавање интерпункције, која појединим сегментима исказивања даје прегледност и одрживост на плану синтаксе. Реч је превасходно о парцелизацији исказа зарезима, чија интензивирана употреба у назначеном типу песничког дискурса има двоструку функцију. Најпре, зарези евидентно служе као средство обележавања резова, синкопа, пулсирања несвесног и наглих „монтажних” срастања диспаратних јединица, те у том смислу они графички маркирају присуство и „савлађивање” зоне предвербалних афективних „енергија” или семиотичког (Кристева). С друге стране, ти знаци полу-прекида, заустављања и обнављања тока, истовремено су остатак и одраз свесне сфере субјективности која контролише смисаоно-граматичку „подлогу” текста, рационално распоређујући паузе између пулсирања неспутаних асоцијација. Сугерисана двострукост интерпункције већ је истицана у надреалистичкој мисли и пракси, и то поводом аутоматског писања: „Ипак остаје да се интерпункција без сумње противи апсолутном континуитету тока о коме је реч, мада изгледа да је

${ }^{7}$ Категорија „имплицитног аутора”, односно „подразумеваног писца”, саставни је део устројства уметничког текста, што је посебно истицано у многим наратолошким теоријама: „'Подразумевани писац' одабира, свесно или несвесно, оно што ми читамо; ми посредним закључивањем долазимо до представе о њему као идеалној, књижевној, сазданој верзији стварног човека; он је збир својих избора" (But 1976: 90). Опис издвојеног аспекта књижевног текста може бити изведен и без антопоморфизација, уз модернију терминологију, те би се на тај начин имплицитни аутор препознао као инстанца „одговорна за систем вредности, норми и значења имплицираних формалном, стилистичком, реторичком и тропичком структуром текста" (Hühn, Schönert 2005: 9). Када се, у интерпретативном процесу, испостави да се инстанца подразумеваног писца управља несталним, противречним и некохерентним начелима, расте могућност да се у њој препозна непоуздан имплицитни аутор (в. O’Neill 1994: 70), што је готово парадигматично у случају лирске субјективности изведене праксама надреалистичке провенијенције, где семантичке импликације и стилско-реторичка динамика одишу непредвидљивошћу и контингенцијом будући да су генерисани принципом несвесног. Тај принцип није само полазиште исказивања лирског Ја, већ је и у основи имплицитног аутора, у темељу, дакле, целокупног идеолошко-семантичког, изражајног и формално-конструктивног устројства текста; могуће разрешење недоумице пред тиме како третирати однос између аутентично несвесног као начела исказивања и његове симулације, понуђено је још у надреалистичкој аутопоетичко-теоријској мисли, у оквиру рефлексије о феномену параноичног искуства: „Симулаиија паранојачког устројства духа даје исте вредности искрености као и несвесно стављање у покрет истог механизма - симулација, довољно усавршена у својој ирационалности, може бити пригрљена, трпљена и изражавана као живо осећање, може постати конкретан предмет подвргнут активном процесу паранојачко-поетске жеље, предмет који даје вредност садржини тог израза, може постати свој сопствени симулакрум" (Popović, Ristić 1985: 112; истакао Г. К.). 
она исто толико неопходна колико и распоред чворова на жици која трепери" (Breton 1979: 39).

Већ током 70-их година Шаламун прибегава још једном поступку који ће (п)остати препознатљив за његов опус. Реч је о уношењу врло широког спектра референци из мита, историје, високе и популарне културе, уметности, религије, затим из парауметничких сфера, јавног живота, уз учестало присуство различитих топонима, од Љубљане до америчких простора. Присуство ове врсте културно-историјских референци поставља питање њиховог статуса унутар песничког дискурса заснованог на дијалектици свесног и несвесног. У контексту анализе лирске субјективности, поготово када говоримо о раним 70-им годинама, присуство сугерисаних елемената и референци доприноси сагледавању ширине хоризонта искуства лирског Ja, али не значајније и његовој кохеренцији. Фрагментарне, деконтекстуализоване, распршене и умножене, назначене културно-медијске, митске и историјске референце, у својој контингентности и непредвидљивости представљају својеврсне супституте несвесног, односно трагове његовог бујања и продора у дискурс, те се могу третирати као означитељи измећу којих су на плану семантичке релеванције разлике нивелисане.

У наведенем контексту парадигматично је лирско Ја у стиховима: „Тебе израеле ћу убити/ у цвеће спуштено тело гилгамеша/ урук, ваба, индијанци на сплавовима/ мете дана, груди и стареж људи/ дроб, коље, поглавар широких друмова/ тихо лепршају анђели, тихо су у мрежама звезда/ неће ме откинути, нећу клечати на траговима возова" (Шаламун 1974: 75). Лирски субјект провизорно формира интертекстуалне релације, али их не доводи до нивоа прегледних значења, већ даје повода да и о интертекстуалним референцама промишљамо као о означитељима посредством којих несвесно, контингентно, асоцијативно - врши уплив у језик/дискурс. То, наравно не потире могућност повремене хомогенизације лирског Ја, тј. моделоване свести која продукује ток исказивања, с тим што је и у тим случајевима ретко реч о прегледнијем и строжијем организовању значења ,призваних” референци. Шири увид у Шаламунов опус, у његову познију фазу, открива нешто суптилније, промишљеније интертекстуалне везе и игре (Đorđević 2002: 79).

\section{Видови аутодескрипције}

Збирка Бела Итака (1972) ослања се на описане поступке из Ходочаuћa за Марушку, одајући утисак минималне, али ипак приметне хомогенизације семантичког плана у многим песмама. „Прошивање” појединих 
текстова анафоричним понављањима, ${ }^{8}$ свакако одражава одређени, иако не преовлађујући, раст рационалног принципа при организацији лирске субјективности. Специфичност Беле Итаке чине изразито аутореференцијално устројене исказне инстанце, односно лирско Ја које се упушта у процедуре неприкривене аутодескрипције, наговештавајући у појединим примерима поступак који ће се, у различитим еманацијама, појављивати у многим каснијим збиркама као препознатљив манир Шаламуновог песничког говора. Реч је о нескривеној аутобиографској ,аури” лирског субјекта услед упућивања на само име аутора, тј. о персони песника која, услед доминантног присуства поступака неонадреалистичког профила, често подразумева хуморни, лудистички, (ауто)иронични третман аутореференцијалних импулса.

Отуд се могу пронаћи овакви стихови: „Зидар сам, свештеник, прашине/ очврснуо као неман, као кора хлеба/ локвањ сам,/ ратник светог дрвећа/ светих снова, кличем с анђелима// замак сам, мртав зид/ лађе превозим, скелеџија путницима" (Шаламун 1974: 97). Лирско Ја себе описује посредством низа метафора које не формирају кохерентну слику субјекта, већ пре сугеришу специфичан принцип саморазумевања, заснован на афирмацији индивидуалних моћи до нивоа омнипотенције и сакрализације сопствених речи, што не дестабилизују ни повремене назнаке наличја таквог става (,,мртав зид”). Варијације наведених поступака постоје и у примерима када лирски субјект постаје Други који специфичном апострофом, сродном слављењу врховног божанства у религијском дискурсу, остварује апотеозу ауторске/песничке фигуре и легитимише њену изузетност: „Ти си геније томаже шаламуне/ ти си сјајан ти си леп/ ти си висок ти си великан/ ти си силан ти си величанствен/ (...)/ ти си без краја и почетка ти си без сенке и страха/ (...) поред тебе је свако светло прескромно поред тебе је/ свако сунце мрак” (Шаламун 1974: 84-85).

Осим што је евидентан иронијски отклон од панегирика упућених било којој позицији (макар и симболичке) моћи, у „лику” лирског субјекта свакако се може препознати и нарцистички/двојнички одраз апострофиране инстанце. Другим речима, лирско Ја се може разумевати као персона која „скрива” другу маску, персону песника, чији ток исказивања даје повода да говоримо о поменутој иронизацији готово поклоничког односа према било којој инстанци, али и да наслутимо виталистичко-лудистичко поверење у перформативну употребу језика, у готово (нео)романтичарску

${ }^{8}$ „Где су коцке глава (...)/ где су јутра сјајна (...)/ где су дрвета на увојке” (Шаламун 1974: 88-89); ,Ти си све ти си планина арарат/ ти си вечит ти си звезда даница/ ти си без краја” (Шаламун 1974: 83). 
ревитализацију ауторске фигуре. Последњи учинак је итекако био комплементаран променама које су, када је реч о статусу уметника у јавном простору, донели поп-арт и поп култура уопште.

У познатој песми „Нistory” из Арене (1973), лирски субјект је опет Други - персона посматрача самог Шаламуна и оног ко промишља о његовој природи („Томаж Шаламун је неман./ Томаж Шаламун је ђуле у ваздуху./ Нико не зна за његову орбиту./ Лежи у полумраку, плива у полумраку./ Људи и ја га гледамо, зачуђени,/ надамо се добру, можда је звезда репатица// (...) // (...) То је Томаж Шаламун, отишао је у радњу,/ са својом женом Марушком купује млеко/ да би пио млеко./ And that's history", Шаламун 1974: 209). Лирским субјектом који посматра и вреднује песника Томажа Шаламуна остварује се двогуби ефекат - и иронизација „великог наратива” Историје, „смењене” тривијализованом сценом одласка песника у радњу, али и предочавање нове улоге уметника/јавних личности у време успона постмодернизма, када се управо на тривијализованим детаљима формира симулакрум њихове појаве, славе и друштвене улоге. „Сенка” поп културе и концептуалне уметности не може да се пренебрегне у назначеном поступку - појава уметника постаје важна колико и само његово дело, тј. може постати само дело.

Непосредна или индиректна аутобиографизација лирског Јa, која, услед центрипеталних токова исказивања и иронијских семантичких импликација често подразумева удаљавање од сваке аутобиографизације у традиционалном смислу, (п)остаће поступак протежне вредности у опусу словеначког песника. Поступци аутотематизације допуњени су, приметили смо, и видовима лирске субјективности која подразумева персону Другог „иза” које се наслућује „лик” апострофираног/перципираног песника. Исказна инстанца би тако „скривала” персону песника која, у „ритуалу” језичког, ентузијастичког самооснаживања, апострофом конституише сопствено парадоксално Ја - истовремено идеализовано и уроњено у свакодневицу, непојамно за окружење и тривијализовано животним рутинама. ${ }^{9}$

Лирско Ја Шаламунове поезије заправо је врло често дато у акту извесног самоодређења, као у стиховима песме „Песак” збирке Арена:

\footnotetext{
${ }^{9}$ При томе не би требало губити из вида да оформљење исказне инстанце у виду Другог који перципира или апострофира ауторску фигуру представља готово огољену параболу улоге Другог у конституисању субјекта. Сами Шаламунови стихови, ипак, и већ описана могућност да у Другом уочимо скривену персону песника, дају повода и да Другог јасније препознамо као „мало друго”, тј. „друго које није заиста друго, већ рефлексија и пројекција ега [...] Оно је истовремено двојник и огледалска слика. Мало друго је стога у целости уписано у имагинарни поредак" (Evans 2011: 90).
} 
„Нисам субјект,/ орман бога сам” (Шаламун 1974: 173). Интензивним и несталним идентификацијама таква исказна инстанца релативизује саму обавезујућу улогу идентитета, бирајући радије осећање омнипотентног витализма и преобиља животних снага, инфатилизовано-мегаломанијско поигравање перформативном улогом језика, способност трансформација и сталних метаморфоза, него самосвесну субјективност која проистиче из картезијанског наслеђа. Отуд није чудно „то што Шаламун нема свог лица, јер су његова сва" (Debeljak 1986: 171). ${ }^{10}$

„Ја сам бијели, брисани простор./ Што се догоди, догоди се” (Šalamun 1980: 7), констатује лирски субјект на почетку Методе анђела (1978) и још једном потцртава контингентност потенцијалних идентификационих релација. Следствено свему томе, идентификационе везе лирског Ја и метафорично евоцираних садржаја често су само условно везе изједначавања; то су пре реализације у језику несвесних садржаја, њихова провизорна појава и нестанак оформљењем и обзнањивањем означитеља. Другим речима, лирско Ја је као специфичан психотоп („,бијели, брисани простор”), „место” парцијалних и апофатичких објава несвесног, самим тим и „поље” непредвидљивих (језичких) могућности. Будући да се може догодити било шта (,што се догоди, догоди се”), и да се лирско Ја може довести у релацију идентификације са било ким/чим језички реализованим на „брисаном простору”, управо тај „простор” се указује као неко/нешто Друго који/које „се изнад свега мора сматрати локусом, локусом у ком се конституише говор" (Evans 2011: 91). ${ }^{11}$

Већ у Арени, а поготово у збиркама Имре (1974), Соко (1974), Друиди (1975), и даље, у Методи анђела, Шаламун више држи до остваривања лирског Ја чији тон исказивања гради илузију да се лудистичке слике и алогички искази надовезују по каквом логичком принципу, да их

\footnotetext{
${ }^{10}$ Многи су примери изненађујућих и семантички дисперзивних аутодескрипција, али и „лица” које за себе жели сам лирски субјект: „Јетра бискупа су стопе моје/ страшне Калифорније”, Шаламун 1974: 175; „Хоћу да будем тако љубазан да бог постанем/ и да са̂м будем изгубљен и заборављен”, Шаламун 1974: 191; „Уста су Дафне и ја сам птица”, Шаламун 1974: 233; „Јесам ја тај соко!”; „Врело сам и роса, коју само/ паук зна” Šalamun 1980: 37; „Златим се под очним капцима људи”; „Ја сам бијели слон”, Šalamun 1980: 66; „Ја сам Буда// (...)// Ја сам/ роса у канти коју дете/ лако носи,/ ја сам бело слатко млеко”, Šalamun 2003: 57).

${ }^{11}$ У песми „Реч” збирке Соко (1974), у једном од, за Шаламунов опус, ретких примера подизања нивоа аутопоетичке експлицитности, лирско Ја парадоксално спаја игру означитеља, ослобођену од арбитрарне функције субјекта, и виталистичко-креационистичку моћ, фундаменталну за Шаламуново схватање песништва и заоденуту готово религиозном ауром у наведеном случају: „Реч је једини темељ света./ Ја сам њен слуга и господар./ И мада дух шаље атоме/ да њуше, пипају, осећају, заиста смо// у пољу где смо с боговима једнаки./ Језик не додирује ништа што би/ било ново. Нема последњег суда,/ нема вишег” (Шаламун 1974: 265).
} 
обједињује пригушен, али кохерентан смисао, или пак да су одјек неког непотпуно откривеног наратива. Лирски субјект отуд ниже констатације које, узвратно, саму исказну истанцу чине привидним гарантом смисла, иако, јасно је из познавања ширег Шаламуновог песничког корпуса, смиcao није императив његовог песништва. „У њедрима/ Латинске Америке/ давио сам/ црне, мрке жабе./ Објављивале су/ томболу која је била помоћ./ Бичем сам им угушио/ ране. Налио/ отрова, који је/ гризао и коначно/ спрао" (Šalamun 1980: 38). У оваквим и сличним лирским микронаративима, лирски субјект представља одређену тачку ослонца при отежаној читалачкој кохезији значења, тј. лирско Ја се ту указује као рецепијентска пројекција језгра претпостављеног смисла тока исказивања, који се опире коначној хомогенизацији.

Врло ретко Шаламунов лирски субјект подразумева конструисање персоне у конвенционалнијем смислу, нпр. у песмама са улогом, при чему и у таквим случајевима долази до осциловања између иронизације уведене исказне инстанце и њене несводивости. Такав је случај са персонама у циклусу „Марија”, где се прозопопејом глас придаје боровници, мишици, јагоди, док се само у првој песми открива лирско Ја које приступа литератури за децу, привидном наивношћу дискретно проблематизујући однос између стварности и фикције („То је књига/ за мале дјевојчице./ (...)/ Јелени/ блоковима својих/ прса ничу из земље/ (...)/ Али ја/ не знам да ли су били/ уистину ту”, „Марија 1”, Śalamun 1978: 33).

Традиционалније видове персона Шаламун остварује у ретким песмама које одражавају одређена референцијална и искуствена полазишта, што постаје нешто фреквентнији поступак у Балади за Метку Крашовец. Ипак, ни лирско Ја таквих Шаламунових песама није претежно рационално устројен субјект. Тако у насловној песми збирке, лирски субјект сведочи о ситуацији референцијалне утемељености, упућујући на одређени датум и околности: „Био је четврти јануар увече у Мексику/ кад сам последњи пут у свом животу остао без/ свести" (Šalamun 2003: 58). У наставку се линеарност зачетог наратива нарушава исказима лирског Ја који одражавају децентрирану инстанцу, вођену надовезивањем асоцијација („Недељама сам је возио/ аутобусима и давао јој све да/ једе: свете/ гљиве и пирамиду Месеца. Са мном се спава на/ тврдој земљи међу/ шкорпијама, али и тамо где береш/ плод и мрмљаш, ти си боја, ти си боја", Šalamun 2003: 58-59). Другим речима, чак и када је полазиште исказивања иницирано посредовањем одређеног референцијално-искуственог садржаја, потпуни „повратак” лирске субјективности на референцијалну и интимистичкомиметичку „подлогу” певања бива трајно онемогућен услед дисперзивно- 
асоцијативне језичке експресије која суспендује референцијалне учинке и стабилизацију тако заснованих значења.

Закључак: лица лирског субјекта као лица ужитка

Наведени спој провизорне хомогенизације и дестабилизације ,јаког” лирског Ја показатељ је да је лирски субјект Шаламунове поезије неподложан психологизацији разумеваној као вид прецизирања емоција, стања, мисли моделоване свести. Ипак, парадокс исказне инстанце Шаламунових стихова је у томе да је, упркос поменутој депсихологизацији, егзистенција лирског Ја „уоквирена” аутобиографским хабитусом и предочена као песничка егзистенција. Она постаје посредничко „место” кумулативног протока језика, асоцијација, успона готово мистичне екстатичности и меланхоличне аутоироније, „простор” реализације радикалне означитељске праксе која истовремено конституише и разграђује субјект, свог „роба” и „господара”, уз минимализовање регулативне улоге рационалног аспекта сопства.

Церебрално полазиште исказивања значајнију поетичку и конструктивну улогу поседовало је у најранијој Шаламуновој стваралачкој фази, у многим текстовима Покера и у познатој песми „Зашто сам фашиста”. Било да хуморно-лудистички прикрива продуктивну повезаност са модернистичким модалитетима субјективности и маскира рационалну страну рефлексије, неретко одговорну за одржање континуитета исказивања, било да иронично-субверзивном дистрибуцијом познатих идеолошких означитеља критикује и тоталитарне режиме и на просвећености засноване друштвене поретке, лирско Ја на почетку Шаламуновог стваралачког пута подразумева одређену равнотежу рационалне сфере субјекта и несвесних флуксева, што резултира нешто прегледнијим семантичким резултатима него у збиркама које следе. У каснијим лирским остварењима, десемантизацијом језика услед радикалне парцелизације израза, контингентним смером исказивања и акциденталним везама међу уведеним означитељима, реализује се лирска субјективност засићена продором несвесних импулса и развлашћена арбитрарне и регулативне улоге када је језик посреди. Несвесно као генеративно начело исказивања и као базични принцип „непоузданог имплицитног аутора", заправо доводи до границе (не)одрживости модернистички концепт исповедно-монолошке лирске субјективности - неоавангардно лирско Ја Шаламунових песама разграђене је границе између свесног и несвесног те чини излишним модернистичко средство „објективних корелатива”, језичког означавања „унутрашњих стања” 
субјекта. Разобручена слободна асоцијативност тек незнатно допушта успон рационалног аспекта субјективности у случајевима када је лирски субјект специфичан по појачаној аутореференцијалности и аутодескрипцији, по парадоксалном споју омнипотенције и дивинизације сопствене појаве са аутоироничним тривијализацијом. То спорадично прати и релативизовање границе текст/емпиријска стварност услед увођења ауторског имена и обликовања нове улоге уметника на прагу постмодерне и света симулакрума.

Поступцима уведеним након песме „Зашто сам фашиста”, Шаламун омогућава да се његова поезија не вреднује по аксиолошко-естетичким критеријума који произлазе не само из традиционалног, већ и из нешто авангарднијег разумевања књижевности. Другим речима, стиче се утисак да Шаламун не пише поезију да би одговорио на било које захтеве - књижевног мњења, песничке традиције, поетичких тенденција, ванлитерарне идеологије. Иако понекад оставља дојам императивне неселективности продукованих асоцијација лирског Ја, лишавајући тако читаоца сигурног упоришта при тумачењу и често суспендујући изградњу сваког кохерентнијег семантичког плана и смисла, Шаламун ослобађа процес исказивања било какве предвидљивости и лирску субјективност напаја на „извору” несвесног. Шаламунови поступци заправо имплицирају став да се о поезији не говори много селекцијом на успела и неуспела остварења, већ да је посреди „мрежа ријечи, која је равна и демократска, свака је точка једнако вриједна" (Brejc 2014: 29). Велики словеначки песник је учинио мање важним вредносни суд и у средиште чина писања и саме рецепције вратио ужитак. Можда сама кумулација, хипертрофија песничких слика и умножавање Шаламунових збирки, као и опирање његове лирике затварању херменеутичког круга, сведоче у прилог Лаканове тезе о сталном узмицању коначног ужитка.

На концу, може се скренути пажња и на потенцијално блумовско читање Шаламунове поезије, али овога пута не у контексту односа словеначког аутора према претходницима, већ у вези са његовим утицајем на јужнословенске песнике од 80-их година до данас. Није неоправдано рећи да је мало која песничка „функција-аутор” (Фуко) тако суверено постављена као у Шаламуновом случају - његов утицај у словеначкој и хрватској поезији већ је осведочен (в. Oblučar 2014: 293-302; Majić 2014: 283-292), а посебно истраживање би могло да покаже да му и нове песничке генерације у Србији много дугују. Ипак, као у сваком другом песничком „случају”, питање је времена када ће уследити превладавање (и) Шаламуна, мада смо склони осећању да ће то бити тежак подухват. У 
сугерисаном контексту чини се да је прикладно завршити Шаламуновом песмом „Бог”: „Ја/ тражим/ безусловну/ љубав/ и/ потпуну/ слободу./ Зато/ сам/ страшан" (Šalamun 2003: 104).

\section{ИЗВОРИ}

Шаламун 1974: Т. Шаламун, Песме, превео Дејан Познановић, Београд: Народна књига.

Šalamun 1978: T. Šalamun, Druidi, preveo Josip Osti, Banja Luka: Glas.

Šalamun 1980: T. Šalamun, Metoda anđela, preveo Josip Osti, Zagreb: Mladost.

Šalamun 2003: T. Šalamun, Balada za Metku Krašovec, preveo Milan Đorđević, Smederevo: Arka.

Šalamun 2013a: T. Šalamun, „Duma 1964”, preveo Ivan Antić, u: Agon, 22 (2013). http://agoncasopis.com/arhiva/stari_sajt/broj_22/o\%20poeziji/1. Tomaz_Salamun_Poker.html 13.9.2018.

Šalamun 2013b: T. Šalamun, „Zašto sam fašista”, preveo Milan Đorđević, u: Agon, 22 (2013). http://agoncasopis.com/arhiva/stari_sajt/broj_22/ o\%20poeziji/1.Tomaz_Salamun_Poker.html 13.9.2018.

Šalamun 2014: T. Šalamun, Poker, preveo Josip Osti, Beograd: Udruženje građana Knjižuljak.

\section{ЛИТЕРАТУРА}

Bart 1971: R. Bart, Književnost, mitologija, semiologija, preveo Ivan Colović, Beograd: Nolit.

Brejc 2014: T. Brejc, „Kada: Sada”, u: Obzorja jezika/ Obnebja jezika: poezija Tomaža Šalamuna. urednik Zvonko, Kovač, Zagreb: FF press, 2014.

Breton 1979: A. Breton, Tri manifesta nadrealizma, prevela Lela Matić. Kruševac: Bagdala, 1979.

But 1976. V. But, Retorika proze, preveo Branko Vučićević, Beograd: Nolit.

Vuković 2010: T. Vuković, „Zamukli majstorov glas”, Povijest hrvatskog jezika/ Književne prakse sedamdesetih, urednik Krešimir Mićanović, Zagreb: Zagrebačka slavistička škola, 161-172.

Grafenauer 2011: N. Grafenauer, „O Zagoričniku”, u: Fantasma epohé. Poezija in/kot igra II. Slovenska avangardna poezija 1965-1983, urednik Andrej Medved, Koper: Hyperion, 1562-1566. 
Де Торе 2001: Г. де Торе, Историја авангардних књижевности, превела Нина Мариновић, Сремски Карловци, Нови Сад: Издавачка књижарница Зорана Стојановића.

Debeljak 1986: A. Debeljak, „Teorija hagiografije”, prevela Bojana Stojanović, Polja, 32, 326 (1986): 171-172.

Denegri 2013: J. Denegri, Srpska umetnost 1950-2000. Sedamdesete, Beograd: Orion art \& Topy.

Despotov 2005: V. Despotov, Čekić tautologije, Zrenjanin: Gradska biblioteka „Žarko Zrenjanin”.

Đorđević 2016: D. Đorđević, „Goli život književnog jugoslovenstva”, u: Sarajevske sveske 49-50 (2016): 159-172.

Đorđević 2002: M. Đorđević, „Na mestu gde se skuplja ambra”, u: Tomaž, Šalamun. Ambra, preveo Milan Đorđević, Beograd: Forum pisaca, 75-80.

Evans 2011: D. Evans, „Šesnaest pojmova Lakanove psihoanalize”, u: QT: Časopis za kvir teoriju i kulturu II, 7 (2011): 88-128.

Žižek 2002: S. Žižek, Sublimni objekt ideologije, prijevod Nebojša Jovanović, Dejan Kršić, Ivan Molek. Zagreb: Arkzin.

Jacek Kozak 2014: K. Jacek Kozak, „Avangardistički divlji lovac: dvojnik avangardnog pesnika", u: Obzorja jezika / Obnebja jezika: poezija Tomaža Šalamuna, urednik Zvonko Kovač, Zagreb: FF press, 65-78.

Lacan 1986: J. Lacan, Četiri temeljna pojma psihoanalize, prevela Mirjana Vujanić-Lednicki, Zagreb: Naprijed.

Majić 2014: I. Majić, „Šalamunove prevedene zbirke na hrvatski i njegova recepcija”, Obzorja jezika / Obnebja jezika: poezija Tomaža Šalamuna, urednik Zvonko Kovač, Zagreb: FF press. 283-291.

Morgan 2006: P. Morgan, “The Family", in: World Fascism: a Historical Encyclopedia, edited by Cyprian P. Blanires, Santa Barbara, Denver, Oxford: ABC Clio.

Oblučar 2014: B. Oblučar, „Tomaž Šalamun u tekstovima hrvatskih pjesnika", u: Obzorja jezika / Obnebja jezika: poezija Tomaža Šalamuna, urednik Zvonko Kovač, Zagreb: FF press, 292-301.

O'Neil 1994: P. O’Neil, Fiction of Discourse: Reading Narrative Theory, Toronto: University of Toronto Press.

Poniž 2001: D. Poniž, Slovenska lirika: 1950-2000, Ljubljana: Slovenska matica.

Popović, Ristić 1985: K. Popović, M. Ristić, Nacrt za jednu fenomenologiju iracionalnog, Beograd: Prosveta.

Fink 2009: B. Fink, Lakanovski subjekt, prevela Ana Štambuk, Zagreb: Kruzak. 
Hünn, Schönert 2005: P. Hünn, J. Schönert, "Introduction: The Theory and Methodology of the Narratological Analysis of Lyric Poetry", in: Hünn Peter, Jens Kiefer. The Narratological Analysis of Lyric Poetry, Berlin, New York: Walter de Gruyter, 1-13.

Šuvaković 1999: M. Šuvaković, Pojmovnik moderne i postmoderne likovne umetnosti i teorije posle 1950. godine. Beograd: SANU; Novi Sad: Prometej.

Goran P. Korunović

\section{“I AM NOT A SUBJECT. I AM GOD'S CLOSET" - THE LYRICAL I IN TOMAŽ ŠALAMUN'S EARLY POETRY}

\section{Summary}

The paper interprets the techniques of fashioning the lyrical subject in the early poetry of one of the major 20th-century Slovenian poets, Tomaž Šalamun, ranging from his débutant collection Poker (1966) to A Ballad for Metka Krašovec (1981). The neoavantgarde aspects of realisation of the uttering instance in the mentioned period are seen in the light of aberration from modernist ways of modelling lyrical subjectivity. The analysis treats the poetical roles of uttering instances of Šalamun's poems and follows their transformation, from the "masked" cerebral core of utterance in Poker, via the more prominent neo-surrealist practices in the later collections, the penetration of the unconscious into the stream of utterance and desemanticisation of language, to a higher self-referentiality of the lyrical I and a paradoxical reaffirmation of the authorial figure.

Keywords: Tomaž Šalamun, lyrical subject, neo-avantgarde, unconscious, irony, subversion. 